\title{
Production of Biogas from Plantain Peels and Swine Droppings
}

\author{
*Nwankwo, Joseph Igwe \\ Department Of Applied Microbiology And Brewing, Faculty Of Applied Natural Sciences, Enugu State \\ University Of Science And Technology, P.M.B.01660 Independence Layout, Enugu, Nigeria.
}

\begin{abstract}
The current over dependence on non-renewable sources of energy such as fossil fuels calls for caution and rethink. This research deals with the production of biogas from plantain peels alone and plantain peels mixed with swine droppings using a 50L metal prototype bio-digester. The plantain peels was pre-decayed for 2 weeks before charging. They were charged as plantain peels alone (PP-A) and plantain peels mixed with swine droppings $(P P-S D)$ into two separate digesters. The waste (PP-A and PP-SD) were subjected to anaerobic digestion for a period of 44days. The cumulative biogas yield for the plantain peels alone (PP-A) was $80.10 \mathrm{dm}^{3}$ while that of plantain peels mixed with swine droppings (PP-SD) was $163.30 \mathrm{~m}^{3}$. The PP-A commenced flammable gas production on the $2^{\text {nd }}$ day while, $P P-S D$ commenced flammable gas production on the $30^{\text {th }}$ day. The PP-SD had the highest cumulative gas yield though with a slow onset of gas flammability. The overall result indicates that the low gas yield of PP-A could be significantly enhanced by blending it with swine droppings.
\end{abstract}

Keywords: Biogas, swine droppings, fossil fuels and plantain peels alone.

\section{Introduction}

Biogas production is mainly brought about through concerted effort of highly delicate group of various anaerobes (Acidogens, Acatogens and Methanogens) via anaerobic digestion to produce gas that contains mainly methane (50-70\%), $\mathrm{CO}_{2}(20-40 \%)$ and traces of other gases such as $\mathrm{CO}, \mathrm{H}_{2} \mathrm{~S}, \mathrm{~N}_{2}, \mathrm{H}_{2}$ and water vapour [1, 2 and 3]. The percentage composition of gases that constitutes biogas varies depending on the nature of substrates and then optimum condition of biogas production process [4,5 and 6]. Biogas is produced by few kinds of microorganisms, usually anaerobes. Animals that eat a lot of plant materials, particularly grazing animals such as cattle, pigs or elephant produce large amounts of biogas. This gas is produced not by the animals themselves but by the billions of microorganisms living in their digestive system [7, 8 and 9]. These methane producing organisms can digest cellulose and are very sensitive to condition in their environment such as temperature, acidity and moisture, which are the basic parameters to note during biogas production. Also, it is important to know that methane fermentation (biogas production) is an important natural process that is responsible for the overall decomposition of natural organic materials residing in anaerobic environment [ 10 and 11]. Biogas as an alternative source of renewable energy has a positive impact on the society by drastically reducing deforestation and helps conserve local energy resources, it also serves as an inexpensive solution to problem of rural fuel shortage [12,13,14 and 15] and serves as good income generator to any society.

The idea that rotting vegetable matters (organic wastes) gives off flammable gas (biogas) has been understood since the ancient Persians. In modern times, the first biogas plant was built in Bombay in 1859; an idea that was brought to UK in 1859, when the gas produced then was used to light street lamps [16, 17, 18, 19 and 20]. This system was developed in the UK and Germany in the early 1900s for the treatment of savage. Centralized drainage systems were being installed in many towns in Europe and anaerobic digestion was seen as a means to reduce the volume of solid matter in the savage [21, 22, 23, 24, 25 and 26]. The gas produced was occasionally used as a source of energy [21, 22, 23 and 24]. The use of farm manure to generate methane was developed for domestic use [25, 27, 28 and 29]. Furthermore, the utilization of microbial activity to treat agricultural, industrial and domestic wastes has been a common practice for about half a century [30, 31, 32, 33, 34 and 35]. Treatment includes the aerobic, activated sludge process and the anaerobic or methane fermentation method [36, 37, 38 and 39], the latter is simple and does not requires imported know-know or components. It is suited to small family or village scale digestion and is the only process utilizing waste as a valuable resource. The use of methane is of great importance to developing countries until recently when its use has been restricted because of other cheaper energy sources [35]. But biogas technology today is a sufficiently significant producer of energy to command the attention of a fair number of countries and agencies.

The aim of this research was to produce biogas from plantain peels and swine using a 50L capacity prototype metallic bio-digester.

\section{Materials and Methods}




\section{Collection of materials}

Plantain peels were collected from Nsukka market and allowed to decay for two weeks, while the swine droppings was collected from the Faculty of Veterinary Medicine, Animal farm, University of Nigeria, Nsukka.

\section{Other materials}

Other materials used for this study include: metal prototype digesters of 50L capacity constructed at the National Center for Energy Research and Development, UNN. Weighing balance (50kg model no. Z051599) and WS graduated imperial and metric scales). It was sued through this study for weighing of waste and water. Thermometer $\left(-10-110^{\circ} \mathrm{C}\right)$ was used for checking temperature of the waste, the slurry and for the ambient temperatures; Jenway digital $\mathrm{pH}$ meter (3510) was used to determine the $\mathrm{pH}$ of the slurries, graduated transparent plastic bucket (for measuring the volume of gas produced by down ward displacement of water) water trough, hosepipes for passage of gas and biogas burner fabricated locally for checking gas flammability.

\section{Sample preparation}

Two samples were involved in carrying out this research, one served as the control (plantain peels alone) and the other served as the experiment (plantain peels and swine droppings).

\section{Plantain peels alone (pp-alone)}

$14 \mathrm{~kg}$ of plantain peels was weighed and soaked with $28 \mathrm{~kg}$ of water in the ratio of $2: 1$ of water to waste. The initial ${ }_{\mathrm{p}} \mathrm{H}$ was 7.0 .

\section{Plantain peels and swine droppings (pp -SD)}

$5 \mathrm{~kg}$ of plantain peels and $5 \mathrm{~kg}$ of swine droppings were weighed making a total of $10 \mathrm{~kg}$ of the waste. This was mixed with $30 \mathrm{~kg}$ of water in the ratio of $3: 1$ of water to waste at $\mathrm{a}_{\mathrm{P}} \mathrm{H}$ of 7.0 .

\section{Experimental set-up}

The plantain peels was charged alone and plantain peels mixed with swine droppings was charged separately. This set up was carried out on the $15^{\text {th }}$ of October, 2009 at the National Center for Energy Research and Development, UNN with a $50<$ capacity metallic prototype digester.

\section{Sample 1 (pp-alone)}

Waste (substrate) was charged in the ratio of 2:1 water to waste ratio. Initial gas production was achieved within $24 \mathrm{~h}$ but commenced flammable biogas production on the $2^{\text {nd }}$ day, but discontinued flammability after 2 days.

\section{Sample II (pp-SD)}

Waste was charged in the ratio of $3: 1$ of water to waste. Initial biogas production started on the $5^{\text {th }}$ day but commenced flammable gas production on the $30^{\text {th }}$ day.

\section{Factors considered before charging}

Certain factors were considered before feeding the digesters with the wastes (substrates). These factors are:

- Size of the digesters: The amount or quality of waste and water that should be fed into the digester until $75 \%$ of the digester was occupied to give room for the rising of the biogas during digestion.

- Nature of the waste: To enable us make a smooth slurry, the waste (plantain peels) was initially chopped into pieces to allow easy decay and break down.

- Proper checking of digester for leakages: The digester was filled with water and checked thoroughly to ensure that there was no linkage.

- Physiochemical analysis of wastes: This involved the determination of the major components of the wastes under study and they include moisture, fat, ash (mineral), protein, carbohydrate and fibers. This analysis provided information relating to the practical utility of the raw material (wastes).

\section{Determination of moisture content}

The hot oven air method of AOAC (1990) was adopted. Porcelain crucibles were washed and dried in an oven at $100^{\circ} \mathrm{C}$ for 2 minutes and these were allowed to cool in the desiccators. Two grams of the new raw wastes were placed into weighed crucibles and then put inside oven at $100^{\circ} \mathrm{C}$ for $4 \mathrm{~h}$. The samples were removed from the oven after which it was cooled and weighed. The drying was continued and all the crucibles with the samples were reweighed until a constant weight was obtained. The percentage moisture was calculated from the loss of weight of the sample. 


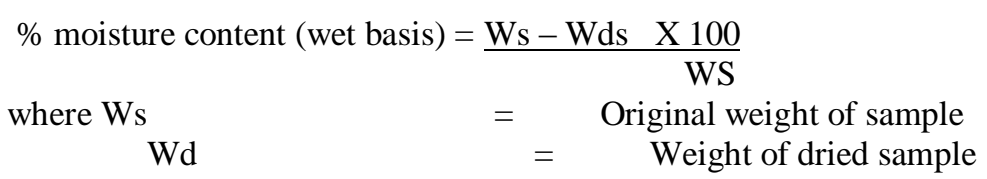

\section{Determination of the Ash content of Raw wastes}

Ash in organic wastes comprises the residue remaining after all the moisture has been removed and the fats, proteins, carbohydrates, vitamins, organic acids etc have been burnt away by ignition at a temperature of about $600^{\circ} \mathrm{C}$. It is usually regarded as a measure of the mineral contents of the raw wastes. Employing the AOAC (1990) method two grammes of finely ground samples were weighed into porcelain crucibles which have been washed, dried in the oven at $100^{\circ} \mathrm{C}$, cooled in desiccators and weighed. The crucibles containing the samples were placed inside the muffle furnance at $600^{\circ} \mathrm{C}$ for $2 \mathrm{~h}$.

After this, the crucible was cooled in the desiccators for 30 minutes and then reweighed.

$\% \mathrm{Ash}=\frac{\mathrm{Was}+\mathrm{Wc}}{\mathrm{Ws}} \quad \mathrm{X}_{100}$

Where Was $\quad=$ weight of ash sample

Wc $\quad=$ weight of crucible

Ws $\quad=$ weight of the original sample

\section{Determination of the crude fiber contents}

Crude fiber of the raw wastes is usually determined to have an idea of the materials that are of cellulose and small ligin. Crude fibre is obtained as organic residue left behind after the raw wastes has been treated under standard condition with organic solvent, dilute mineral acids such as $\mathrm{H}_{2} \mathrm{SO}_{4}$ and sodium hydroxide. Using AOAC (1990) methods, two grammes of the sample were weighed into a $600 \mathrm{ml}$ beaker and mixed with $200 \mathrm{ml}$ of $0.125 \mathrm{~m} \mathrm{H}_{2} \mathrm{SO}_{4}$. This was digested for 30 minutes under controlled conditions. The mixture was filtered under suction, washed with hot distilled water until the washing is no longer acidic. The residue was then transferred to a beaker and boiled for minutes with $200 \mathrm{ml}$ of a solution containing $1.25 \mathrm{~g}$ of $\mathrm{NaOH}$ per $100 \mathrm{ml}$. The digested sample was then washed with $1 \% \mathrm{HCl}(1 \mathrm{~g}$ in $100 \mathrm{ml}$ of acid) to neutralize the $\mathrm{NaOH}$ solution several times with hot distilled water.

The final residue was obtained by filtering through a linen cloth on a fluted funnel. This residue collected was put into a weighed crucible and dried at $100^{\circ} \mathrm{C}$ for $2 \mathrm{~h}$ in the electric oven. It was then cooled in a desiccators weighed and ashed. The ash obtained was cooled in a desiccators for 30 minutes and weighed.

$$
\begin{array}{llll}
\% \text { Crude fibre } & = & \text { Was }+\mathrm{Wc} \quad \mathrm{Ws} & 100 \\
\text { Where } & \mathrm{Wc} & & \text { weight of crucible } \\
\text { original weight of sample } & \text { treated sample before ashing }
\end{array}
$$

\section{Determination of Crude Fat content}

Crude fat content in the wastes was determined using soxhlet extraction method (Pearson, 1976). The soxhlet fat extraction method involves continuous extraction of waste sample with non polar organic solvent such as petroleum ether sample. In order to carry out this, the extraction flask was washed thoroughly and placed in hot oven to dry for 30 minutes. It was then cooled in a desiccator. Two grammes of ground wastes samples was accurately weighed and transferred into rolled ash filter paper and placed inside the extractor thimble.

The thimble was then placed inside the soxhlet extractor. Some quantity of petroleum ether was poured inside the extraction flask ( 3 quarter of the volume of the flask). The soxhlet was connected to the flask and in turn to the condenser. The heater was switched on and set in such a way that the temperature should not exceed the boiling point of petroleum ether used. The extraction was allowed to run for $4 \mathrm{~h}$ after which the petroleum ether was recovered. The oil collected in the flask was dried in an oven at $100^{\circ} \mathrm{C}$, it was weighed and percentage fat calculated as follows:

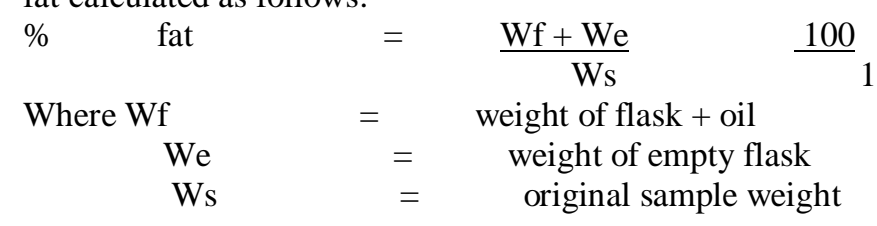

Determination of total nitrogen/crude protein in the wastes 
The micro-kyetdal method as described in pearson (1976) was used. The method involved estimation of the total nitrogen in the wastes and subsequent conversation of the nitrogen to protein with the assumption that all protein in the wastes are present as nitrogen. Using a conversion factor of 6.25 , the actual percentage of protein in the waste was calculated as shown below.

$\%$ crude protein $=\%$ Nitrogen $\mathrm{x} F$

Where, $\mathrm{F} \quad=$ conversion factor

Micro-kyeldahl digestion- distillation apparatus and 50ml kyeldahl flask were used in carrying out the analysis.

Digestion: Two grammes of the ground wastes sample were weighed into kyeldahl flask. Catalysts such as sodium sulphate and copper sulphate were added in the flask in the ratio of 3:1. Oxidizing agent like conc. $\mathrm{H}_{2} \mathrm{SO}_{4}(15 \mathrm{ml})$ was also added. Five glass beads were added to the flask to prevent too much bumping during heating. Heating was carried out cautiously on digestion rack under fune cupboard until a greenish dear solution appeared. The digest was allowed to clear for about 30minutes and allowed to cool. About $10 \mathrm{ml}$ of distilled water was added to avoid caking after which the digest was transferred with several washings into a $25 \mathrm{ml}$ volumetric flask and made up to the mark with distilled water.

Distillation of the protein: Distillation was carried out using kyeldahl distillation apparatus. A 50ml concaidmellyl red and blue indicator was placed under condenser of distillation apparatus so that the tip was $2 \mathrm{~cm}$ inside the indicator, a $10 \mathrm{ml}$ of $40 \% \mathrm{NaOH}$. The heat energy that was released was absorbed by the water surrounding the bomb calorimeter and gave rise to increase in temperature of the water that was used to estimate the energy value of the sample. Two grammes of the sample were pelleted and burnt in a diabolic oxygen bomb calorimeter. The heat of combustion was calculated as the gross energy. Energy content

Where $=$
$=$

$$
\begin{aligned}
= & \\
& = \\
& = \\
& =
\end{aligned}
$$

W x T $-2.3 \mathrm{~L}-\mathrm{V}$

Ws (original sample weight)

Energy equivalent or water equivalent of calorimeter

Temperature rise

Titre

Original sample weight

Determination of total solids: Determination of total solid waste is an effective way of finding out the amount of nutrient that will be available for bacterial action during digestion. It is made up of digestible and non digestible materials. Meynell (1982) method was used. Five grammes of the raw waste were dried in an oven at $105^{\circ} \mathrm{C}$ for $5 \mathrm{~h}$. The dried sample was cooled in a desiccator and then weighed the weight obtained after all moisture loss is the total solid.

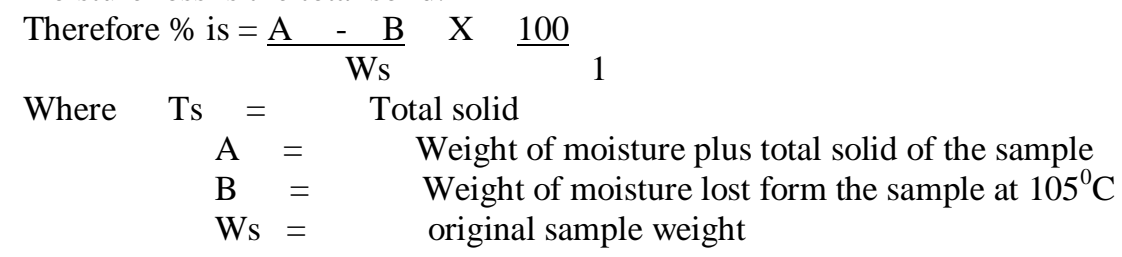

Determination of volatile solids: Volatile solids is the true organic mater available for bacterial action during digestion. The analysis was carried out using Meynell (1982) method. One gramme of sample solid residue from solid determination was heated in muffle furnance at $600^{\circ} \mathrm{C}$ for $2 \mathrm{~h}$. After this, the heated residue was cooled in a dessicator and weighed.

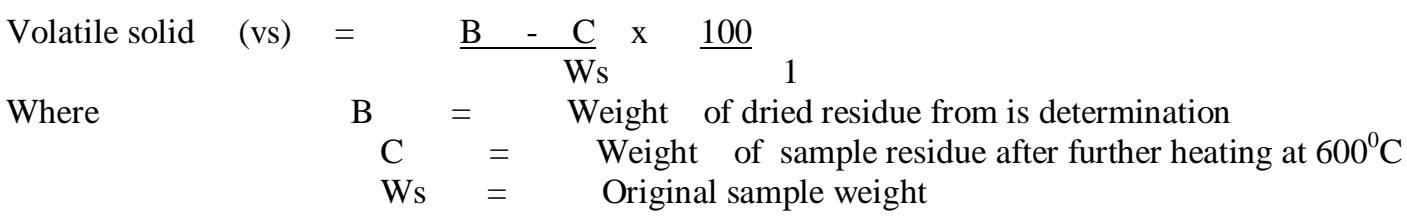

Determination of carbon contents: This was determined by method of Walkey Black (1934). One gramme of the finely ground sample was weight into $500 \mathrm{ml}$ conical flask. Ten milliliters, $(19 \mathrm{ml})$ of potassium dichromate $(1 \mathrm{~m})$ was poured inside the flask and the mixture was swirled. Twenty milliliters $(20 \mathrm{ml})$ of conc. $\mathrm{H}_{2} \mathrm{SO}_{4} \mathrm{was}$ added and the flask was swirled again for 1 minute in a fume cupboard. This mixture was allowed to cool for 30 minutes after which $200 \mathrm{ml}$ of distilled water, $1 \mathrm{~g}$ of $\mathrm{NaF}$ and $1 \mathrm{ml}$ of diphenylamine indicator were added. The mixture was shaken and titrated with ferrous ammonium sulphate solution in the burette. The blank was also treated similarly.

$\%$ carbon $=\mathrm{B}-\mathrm{T} \times \underline{0.003} \times \underline{100}$ 
Ws 1

$\begin{aligned} \text { Where } \mathrm{B} & = & \text { Blank titre Ws } \\ \mathrm{T} & = & \text { sample titre } \\ \mathrm{C} & = & \text { Conc. of Fe solution } \\ \mathrm{Ws} & = & \text { Original sample weight }\end{aligned}$

Solution was added to the digested sample in the apparatus through funnel stop cork. Closing the steam by pass and opening the inlet stop cork on the steam yet arm of the distillation apparatus then started off the distillation. The distillate was collected in the collected in the conical flask $(3.5 \mathrm{ml})$ with its indicator methyl red and blue. Filtration was then carried out using $0.01 \mathrm{~m} \mathrm{Hcl} \mathrm{till} \mathrm{pink} \mathrm{colouration.}$

$$
\% \text { Nitrogen } \quad=\frac{\text { Titre } \times 0.0014 \times 250 \times 100}{\mathrm{Ws}} 1
$$

$\%$ Crude protein $=\% \mathrm{~N} \times 6.25$

$\mathrm{N}$ in food waste conc $\mathrm{H}_{2} \mathrm{SO}_{4}+\left(\mathrm{NH}_{4}\right)_{2} \mathrm{SO}_{4}$

$\left(\mathrm{NH}_{4}\right)_{2} \mathrm{SO}_{4}+2 \mathrm{NaOH}$ catalyst $\mathrm{Na}_{2} \mathrm{SO}_{4}+2 \mathrm{H}_{2} \mathrm{O}+2 \mathrm{NH}_{2}$

Ammonia generated was collected in excess boric acid

$2 \mathrm{NH}_{3}+2 \mathrm{H}_{3} \mathrm{BO}_{3} \quad 2 \mathrm{NH}_{3} \mathrm{H}_{2} \mathrm{BO}_{3}$

The nitrogen estimated by titration of ammonium borate produced with a standard $\mathrm{HCl}$ or $\mathrm{H}_{2} \mathrm{SO}_{4}$.

Determination of Energy content: This was carried out using AOAC (1975) bomb calorimeter method. Ti ignites the waste sample in oxygen bomb calorimeter (under high pressure of oxygen gas usually 25atm). This helped to bring about oxidation of organic constituents of the waste sample to water and carbon dioxide while oxidizing some elements such as Sulphur, Nitrogen and phosphorus and resultant release of heat energy.

Microbial analysis: Microbial analysis involves the isolation, identification and number of micro-organism present in the set up. Surface viable count method is also used. This is the miles and Misra (1935) method.

Media preparation: Nutrient of weight $6.2 \mathrm{~g}$ was mixed with 1 litre of water also $6.2 \mathrm{~g}$ of Sabourand Dextrose Agar (SDA) was weighed and mixed with 1 litre of water into different conical flask. The mixtures were agitated to have a uniform mixture. Heating was carried out to ensure melting of the Agar. The mixtures were sterilized for 15 minutes at $121^{\circ} \mathrm{C}$. It was allowed to cool to $45-50^{\circ} \mathrm{C}$ and then poured on the petri-dishes to solidify.

Isolation of bacteria and yeast: One gramme of the waste was carefully weighed and transferred into sterile test -tubes. Sterile saline solution $(10 \mathrm{ml})$ was transferred to the sterile test-tubes containing the waste sample. The mixture shaken thoroughly to obtain a uniform suspension, which was allowed to set, the supernatant served as the inoculums. Using a sterile loop a loop-full of the supernatant was collected and streaked on the nutrient agar plate. The plates were incubated at $37^{\circ} \mathrm{C}$ for $24 \mathrm{~h}$. After the incubation period, the plates were carefully inspected for growth of bacteria. Developed single, discrete colonies representing organisms were respectively sub-cultured into sterile nutrient agar slant and preserved as stock cultures for identification purpose.

\section{Identification tests for bacterial isolates}

Gram test: Smears of the pure colonies were made on clean grease free glass slides with normal saline. The smears were air dried and heat fixed. They were kept on a staining rack positioned in a staining manner and flooded with crystal violet for 1 minute and immediately rinsed off. The glass slides were titled and decolorized with acetone until the drained acetone becomes colourless. They were rinsed and finally count stained with carbol-fushin for 1 minute. The glass slides were rinsed off, blotted, air dried and viewed under the microscope. Catalase test (slide method):A drop of hydrogen peroxide (3\%) was made in a clean grease free glass slide. Using a sterile rod, a 24hours colony of each of the test organisms was test organisms was picked and smeared on the hydrogen peroxide. Bubble of gas which indicated positive test was observed (Pearson, 1996).

Coagulase test (slide method): 15 milliliter of healthy human blood was centrifuged and the plasma obtained. Smears of the test organisms were made on clean grease- free slides at two different sites. The site containing the water served as the control (Miles and Misra, 1938).

\section{Motility test (hanging drop method)}

Peptone water $(3 \mathrm{ml})$ was inoculated with a colony of the test organisms and then incubated overnight at $37^{\circ} \mathrm{C}$. A ring of plastercine was placed on a clean slide and inverted over a drop of the culture broth on the centre of a clean cover slip. With quicker movement the slide inverted so that cover slip is the uppermost and the preparation was examined under the microscope with 110 and x 40 objectives. Motility was observed to show an active displacement in space and time given directions (Miles and Misra, 1938).

Indole test (Erhlich's method) 
A loop full of the test organisms was cultured into peptone water $(5 \mathrm{ml})$ for 3 days. After the 3 days incubation, 2 drops of xylene and 3 drops already prepared indole reagent (Erhlichs method) were added to the culture broth. A pink or red ring on the surface of the culture broth was observed as a positive test.

\section{Oxidase test (filter paper method)}

A piece of filter paper was soaked with 2 drops of freshly prepared oxidase agent (tetra methyl-pphyenylenediamine-dihydrochloride). A colony of the test organism was the smeared on the oxidation filter paper. A purple coloration on the smeared filter paper within 10 seconds was noticed.

\section{Isolation of fungi}

The procedure adopted for isolation and identification of bacteria was also used for the isolation and identification of fungi. In place of nutrient agar, sabourand Dextrose Agar (SDA) and $1 \mathrm{~g}$ of the plates. The plates were incubated at 25 to $28^{\circ} \mathrm{C}$ for 7 days. The fungi present in each of the waste were identified by microscopy and their colonial appearance.

\section{Identification test for fungi isolates}

Cotton blue is the most popular stain used in my cological staining. Lactophenol is the liquid that serves as mountant for fungal specimens. The lactophenol and cotton blue are usually prepared together and the combination is called lactopheno cotton blue, which serves as a stain and as a stain and as a mountant. Two drops of lactophenol cotton blue stain was dropped on a clean slide using inoculating loop, the organisms was picked and carefully placed on the slides with stain. The mycelium was leased out carefully to avoid breakage of the hyphe-cells cover slip was placed on top of the organisms carefully to avoid air bubbles. Excess stain outside the cover slip was blot dried. The preparation was observed under the microscope using the lower power objective tens.

\section{Determination of number of living organisms}

Surface viable count method was used. By diluting the suspension obtained from the isolation of bacteria with sterile water using a sterile pipette. The aim was to obtain a dilution that contained approximately 30 cells per $0.015 \mathrm{ml}$. Agar plates were prepared and the under sides of the plates were divided into eight segments with a maker. A drop of the suspension was inoculated on each segment. These plates were then incubated for 24 hours at $37^{\circ} \mathrm{C}$. Developed colonies were counted using the expressions below.

Mean count

$=\quad$ number of colonies in each segment

8

Total viable count

$=\quad$ Mean count $(\mathrm{cfu}) \times$ dilution factor $(\mathrm{cfu} 1 \mathrm{ml})$

Volume per drop $(0.05 \mathrm{ml})$

Note: The higher the dilution factor, the less turbid the solution.

\section{Temperature measurement during digestion period}

Daily recording of the ambient temperature of the digesters were taken throughout the period of the experiment and also the daily temperature of the slurry was recorded (taken) with liquid in glass thermometer (10 to $11^{0} \mathrm{C}$ ).

\section{${ }_{\mathrm{PH}} \mathrm{measurement}$ during digestion}

Daily checking and recoding of the ${ }_{\mathrm{p}} \mathrm{H}$ (hydrogen ion concentration) of the set up (digesters) was done throughout the digestion period. The ${ }_{\mathrm{p}} \mathrm{H}$ was ascertained using the Jeanway $3020{ }_{\mathrm{p}} \mathrm{H}$ meters. The ${ }_{\mathrm{p}} \mathrm{H}$ meter was standardized using buffer solutions for ${ }_{\mathrm{p}} \mathrm{H} 4.0$ and 9.0. Sufficient time was allowed for stabilization of the $\mathrm{pH}$ meter before taking the readings.

III. Results

TABLE 1: Physiochemical Analysis of plantain waste and swine droppings

\begin{tabular}{|l|l|ll|}
\hline Parameters & Plantain peels alone & $\begin{array}{l}\text { Plantain peels and swine } \\
\text { droppings }\end{array}$ \\
\hline Moisture & 4.20 & 11.40 & \\
\hline Ash & 43.70 & 36.60 & \\
\hline Crude fat & 2.40 & 1.40 & \\
\hline Crude fibre & 16.20 & 20.10 & \\
\hline Crude protein & 9 & 9.20 & \\
\hline
\end{tabular}


Production of Biogas from Plantain Peels and Swine Droppings

\begin{tabular}{|l|l|l|}
\hline Crude nitrogen & 1.46 & 1.47 \\
\hline Carbon & 47.88 & 23.94 \\
\hline Total slides & 95.80 & 88.60 \\
\hline Volatile slides & 53.10 & 52.00 \\
\hline Energy & 4.193 .45 & 3.45 \\
\hline C /N ratio & 32.79 & 16.46 \\
\hline PH at point of charging & 7.0 & 7.0 \\
\hline
\end{tabular}

Table 2: Daily volume of biogas production (liters) for plantain peels alone and plantain peels with swine

\begin{tabular}{|c|c|c|}
\hline DAYS & $\begin{array}{l}\text { PLANTAIN } \\
\text { PELLS ALONE } \\
\text { (PP-A) }\end{array}$ & $\begin{array}{ll}\text { PLANTAIN } & \text { PEELS AND } \\
\text { SWINE } & \text { DROPPINGS } \\
\text { (PP-SD) } & \\
\end{array}$ \\
\hline 1 & 6 & 0 \\
\hline 2 & 13.2 & 0 \\
\hline 3 & 6 & 0 \\
\hline 4 & 5.8 & 0 \\
\hline 5 & 4 & 1 \\
\hline 6 & 2 & 1.5 \\
\hline 7 & 1.5 & 32 \\
\hline 8 & 1.3 & 2 \\
\hline 9 & 1.5 & 0 \\
\hline 10 & 0.5 & 0.5 \\
\hline 11 & 2 & 1 \\
\hline 12 & 2 & 0 \\
\hline 13 & 1 & 0 \\
\hline 14 & 0 & 1 \\
\hline 15 & 1 & 1 \\
\hline 16 & 0.5 & 1 \\
\hline 17 & 1 & 1.5 \\
\hline 18 & 3 & 3 \\
\hline 19 & 1 & 1.5 \\
\hline 20 & 1 & 3.2 \\
\hline 21 & 1 & 2.3 \\
\hline 22 & 1.5 & 2.8 \\
\hline 23 & 1.2 & 2.5 \\
\hline 24 & 2 & 2.5 \\
\hline 25 & 1 & 2 \\
\hline 26 & 1 & 2.5 \\
\hline 27 & 1 & 2.5 \\
\hline 28 & 1 & 3.5 \\
\hline 29 & 1 & 4 \\
\hline 30 & 1 & 4 \\
\hline 31 & 0.5 & 6.8 \\
\hline 32 & 0 & 7.4 \\
\hline 33 & 0 & 6.8 \\
\hline 34 & 1 & 14.2 \\
\hline 35 & 1 & 18.8 \\
\hline 36 & 1 & 11.7 \\
\hline 37 & 1 & 8.9 \\
\hline 38 & 1.2 & 9.8 \\
\hline 39 & 0.5 & 4.5 \\
\hline 40 & 1.5 & $\begin{array}{l}9.8 \\
\end{array}$ \\
\hline 41 & 1 & 3.1 \\
\hline 42 & 1 & 3.1 \\
\hline 43 & 1.9 & 3.1 \\
\hline 44 & 2.5 & 4 \\
\hline
\end{tabular}


Production of Biogas from Plantain Peels and Swine Droppings

\begin{tabular}{|l|l|l|}
\hline CUMULATIVE BIOGAS YIELDS & 80.1 & 163.3 \\
\hline CUMULATIVE MEAN & 1.82 & 3.71 \\
\hline
\end{tabular}

Table 3: Lag period cumulative gas yield and mean volume of gas

\begin{tabular}{|l|l|l|}
\hline Parameters & Plantain peels alone & $\begin{array}{l}\text { Plantain peels and swine } \\
\text { droppings }\end{array}$ \\
\hline Lag period & 1 day & 29 days \\
\hline Cumulative volume & 80.10 & 163.30 \\
\hline Mean & 1.82 & 3.71 \\
\hline
\end{tabular}

Table 4: Microbial analysis -total viable count

\begin{tabular}{|l|l|l|l|}
\hline Parameters & Plantain peels alone & $\begin{array}{l}\text { Plantain peels and swine } \\
\text { droppings }\end{array}$ \\
\hline At charging & $5.92 \times 10^{6}$ & $4.25 \times 10^{5}$ & \\
\hline At flammability & $6.32 \times 10^{7}$ & $3.08 \times 10^{7}$ & \\
\hline At the packaging & $6.32 \times 10^{7}$ & $5.78 \times 10^{7}$ & \\
\hline At the end of digestion & $3.92 \times 10^{6}$ & $6.18 \times 10^{7}$ \\
\hline
\end{tabular}

Table 5: Bacterial identification scheme for the recovered isolates

\begin{tabular}{|c|c|c|c|c|c|c|c|c|c|c|c|c|}
\hline $\begin{array}{l}\text { Samp } \\
\text { le }\end{array}$ & $\begin{array}{l}\text { Coloni } \\
\text { al } \\
\text { appear } \\
\text { ance }\end{array}$ & $\begin{array}{l}\text { Gra } \\
\mathrm{m} \\
\text { react } \\
\text { ion } \\
\end{array}$ & $\begin{array}{l}\text { Cata } \\
\text { lase }\end{array}$ & $\begin{array}{l}\text { Coag } \\
\text { ulase }\end{array}$ & $\begin{array}{l}\text { Moti } \\
\text { lity }\end{array}$ & $\begin{array}{l}\mathrm{D} \\
\mathrm{Na} \\
\mathrm{se}\end{array}$ & $\begin{array}{l}\text { Novob } \\
\text { lesm }\end{array}$ & $\begin{array}{l}\text { Citr } \\
\text { ate }\end{array}$ & $\begin{array}{l}\text { Ind } \\
\text { ole }\end{array}$ & $\begin{array}{l}\text { Oxid } \\
\text { ase }\end{array}$ & $\begin{array}{l}\mathrm{Ge} \\
\mathrm{rm} \\
\text { tub } \\
\mathrm{e}\end{array}$ & inference \\
\hline $\begin{array}{l}\text { Plant } \\
\text { ain } \\
\text { peels } \\
\text { alone }\end{array}$ & $\begin{array}{l}\text { Mediu } \\
m \text { size } \\
\text { elevat } \\
\text { ed on } \\
\text { nutrie } \\
\text { nt agar }\end{array}$ & $\begin{array}{l}+\mathrm{ve} \\
\text { cocc } \\
\mathrm{i} \\
\text { clust } \\
\text { ers }\end{array}$ & $+\mathrm{ve}$ & $+\mathrm{ve}$ & $+\mathrm{ve}$ & $\begin{array}{l}- \\
\text { ve }\end{array}$ & $+\mathrm{ve}$ & $-\mathrm{ve}$ & -ve & $-\mathrm{ve}$ & -ve & $\begin{array}{l}\text { Staphylo } \\
\text { coccus } \\
\text { areus }\end{array}$ \\
\hline \multirow[t]{2}{*}{$\begin{array}{l}\text { Plant } \\
\text { ain } \\
\text { peels } \\
\text { and } \\
\text { swine } \\
\text { dropp } \\
\text { ings }\end{array}$} & $\begin{array}{l}\text { Circul } \\
\text { ar, } \\
\text { conve } \\
\text { x, } \\
\text { smoot } \\
\mathrm{h} \\
\text { coloni } \\
\text { es } \\
\text { with } \\
\text { district } \\
\text { edge } \\
\text { on } \\
\text { nutrie } \\
\text { nt agar }\end{array}$ & $\begin{array}{l}\text {-ve } \\
\text { rods }\end{array}$ & $-v e$ & -ve & $+\mathrm{ve}$ & $\begin{array}{l}\text { - } \\
\text { ve }\end{array}$ & $-\mathrm{ve}$ & $-\mathrm{ve}$ & $+\mathrm{ve}$ & -ve & $-\mathrm{ve}$ & E. coli \\
\hline & $\begin{array}{l}\text { Cluste } \\
\text { rs of } \\
\text { mediu } \\
\mathrm{m} \text { size } \\
\text { coloni } \\
\text { es on } \\
\text { DNA }\end{array}$ & $\begin{array}{l}+\mathrm{ve} \\
\text { rods }\end{array}$ & -ve & -ve & $-\mathrm{ve}$ & $\begin{array}{l}+\mathrm{v} \\
\mathrm{e}\end{array}$ & $-v e$ & $-\mathrm{ve}$ & $-\mathrm{ve}$ & $-\mathrm{ve}$ & $-\mathrm{ve}$ & $\begin{array}{l}\text { Microco } \\
\text { spp. }\end{array}$ \\
\hline
\end{tabular}

Table 6: Yeast identification scheme for the recovered isolates

\begin{tabular}{|l|l|l|l|l|}
\hline Sample & Gram reaction & Germ tube & Odour & Inference \\
\hline $\begin{array}{l}1 . \quad \text { Plantain } \\
\text { peels alone }\end{array}$ & $\begin{array}{l}\text { Gram positive } \\
\text { cocci }\end{array}$ & $+\mathrm{ve}$ & $\begin{array}{l}\text { Fermented } \\
\text { cassava smell }\end{array}$ & Candida albicans \\
\hline $\begin{array}{l}2 . \quad \text { Plantain } \\
\text { peels and swine } \\
\text { droppings }\end{array}$ & $\begin{array}{l}\text { Gram positive } \\
\text { cocci (bud) }\end{array}$ & -ve & Foul smell & $\begin{array}{l}\text { Saccharomyces } \\
\text { Spp }\end{array}$ \\
\hline
\end{tabular}

Table 7: Identification scheme for the recovered isolates 


\begin{tabular}{|c|c|c|c|}
\hline Sample & $\begin{array}{l}\text { Colonial appearance } \\
\text { on SDA }+\mathrm{C}\end{array}$ & $\begin{array}{l}\text { Lactophenol cotton } \\
\text { blue microscopic } \\
\text { appearance }\end{array}$ & Inference \\
\hline Plantain peels alone & $\begin{array}{l}\text { Grayish coloration with } \\
\text { white boards }\end{array}$ & $\begin{array}{l}\text { Septate hyphae, conidia } \\
\text { borne on the } \\
\text { conidiospores in } \\
\text { multilink chairs like a } \\
\text { paint brush }\end{array}$ & Penicillium spp \\
\hline $\begin{array}{l}\text { Plantain peels } \\
\text { swine droppings }\end{array}$ & Blackish colouration & $\begin{array}{l}\text { Septate hyphae } \\
\text { conidiosphores borne } \\
\text { laterally on the hyphae, } \\
\text { non-septate, numerous } \\
\text { sterigmata proceed from } \\
\text { the apical club-shaped } \\
\text { swellings conidia borne } \\
\text { in chains of sterigmata }\end{array}$ & Aspergillus niger \\
\hline $\begin{array}{l}\text { Plantain peels and } \\
\text { swine droppings }\end{array}$ & Greenish colouration & $\begin{array}{l}\text { Septate hyphae } \\
\text { conidiosphores borne } \\
\text { laterally on the hyphae, } \\
\text { non-septate, numerous } \\
\text { sterigmata proceed from } \\
\text { the apical club shaped } \\
\text { swellings conidia borne } \\
\text { in chains of stergimata }\end{array}$ & Aspergillus niger \\
\hline
\end{tabular}
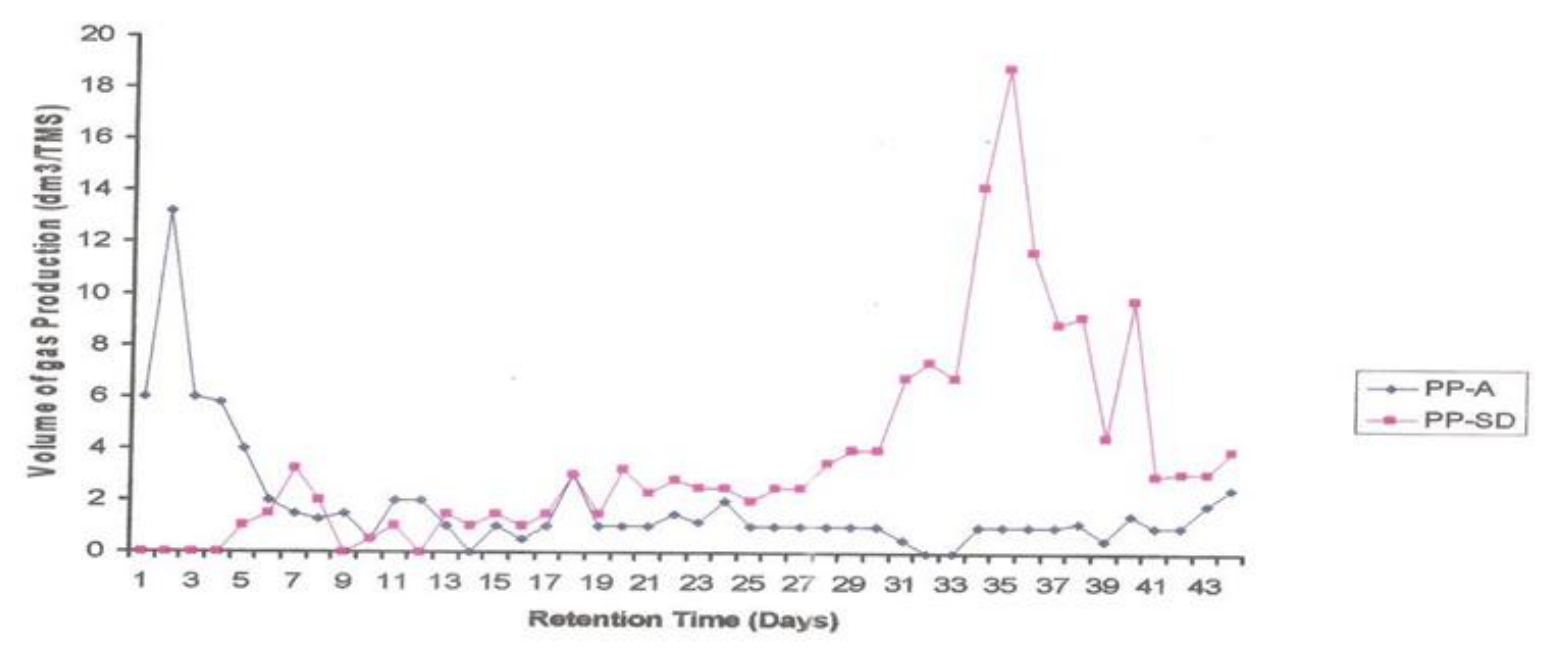

\section{Fig. 2: Daily Biogas Production "Volume of Production (dm3/TMS)}

\section{Discussion}

This research was carried out under ambient temperature range of $26^{\circ} \mathrm{C}$ to $36^{\circ} \mathrm{C}$ and slurry temperature of $32^{\circ} \mathrm{C}$ to $42^{\circ} \mathrm{C}$ within a retention time of 44 days. The daily biogas production is graphically represented in figure 1. The digester containing plantain peels alone (control) commenced biogas production within $24 \mathrm{~h}$ of charging the digester, while the plantain peels and swine droppings commenced gas production from the $5^{\text {th }}$ day. While the onset of gas flammability took place at different lag periods (table 3). The plantain peels Alone (PPA) had the shorter onset of gas flammability of $24 \mathrm{~h}$ with low cumulative biogas yield of $80.1 \mathrm{dm}^{3} /$ Total Mass of Slurry (TMS).

Though, the lag period (which is from the time of charging the digester to the time of onset of gas flammability) was short, the system drastically reduced gas production to almost nil after 5 days throughout the retention period and the little gas produced was no longer flammable. A biogas that will satisfy the basic need for cooking and lighting must be flammable. If it burns, it implies that the methane content is at least $45 \%$, if it does not burn, it means the methane content is less than $45 \%$ and contains mainly $\mathrm{CO}_{2}$ and other gases [12 and 15]. The PP - Alone had adequate physiochemical properties to effect reasonable biogas production. The physiochemical properties of wastes are the properties inherent in the waste that enable it to produce biogas the 
way it does, its ash content was higher. Ash content of the waste gives an indication of the mineral component of the waste showing that it would be a very good bio-fertilizer producing enough mineral source to the soil. Its volatile solids (vs) (which is the biodegradable protein of the waste) was enough and even higher than that of plantain peels with swine droppings. The energy content was also higher, showing that it would be a very good feed for biogas production when properly utilized. Adequate physiochemical properties are known to favour efficient biogas production [10]. However, the carbon to nitrogen ratio was slightly low, it was not enough to have affected the performance of this waste adversely. However, plant wastes are known to be difficult to biodegrade. This is because of ligin, cellulose, hemicelluloses, pectin and plant wax in the waste which is not easy to breakdowns and which again leads to an acidic condition. The microbes that convert waste to biogas are sensitive to $\mathrm{pH}$ and survive optimally at a $\mathrm{pH}$ range of $6.5-8.0$ [1, 2, 3 and 4]. This may have contributed to the poor performance of the waste; blending plantain peels with swine dropping improved the cumulative biogas yield by more than $100 \%$, though the onset of gas flammability was sustained after it had set in. The blend (PP$\mathrm{SD}$ ) was very slow in gas production at the beginning and only picked up seriously from the $27^{\text {th }}$ day. The carbon /nitrogen ratio was poor and fell below the optimum range required for effective biogas production.

The nutrient level, energy content and nutrient (fat) were lower. These factors may also contribute to the performance in terms of onset of gas flammability. Animal wastes are known to be good starters for the poorer producing ones since they are better biogas producers. They have also been used for optimizing biogas production for various plant wastes [21, 22, 23 and 24]. However, blending the plantain peels with swine droppings did not improve appreciably the physiochemical properties of the wastes but had a decay onset of gas flammability which has sustained till the end of the digestion (fig.1). The result of microbial total viable count (TVC) shows the progression of the microbes that converted the waste to biogas (Table 4). The microbial load started out lower, but then increased towards the end of the retention period which shows the death curve for the microbes. Table 5 shows the result of the bacteria identification test of the two samples. Staphylococcus aureus and Escherichia coli were identified in the plantain peels and swine dropping waste. Yeast were also identified from the wastes (Table 6) Candida albicans and Saccharomyces spp were identified from plantain peels alone and plantain peels and swine droppings isolates respectively. Fungi, Penicillium spp and Aspergillus niger were identified from the recovered isolates from the plantain peels alone while Aspergillus niger, Penicillium spp and Aspergillus funigus were identified from plantain peels with swine droppings waste (Table7).

\section{Conclusion}

In conclusion, this study has shown that at last there is hope for us to harness safe renewable alternative energy form waste which was formerly seen as environmental contaminants. This research also shows a new source for wealth creation and at the same time decontaminate the environment by waste recycling and transformation. Finally, its important to suggest that apart from swine droppings other animal wastes such as cow, rabbit and poultry wastes can also be utilized to optimized biogas production.

\section{Recommendations}

Biogas technology has been used in several decades in the past but it is still a developing technology. From the result of this research, the following recommendations were made to further enhance the process of biogas technology.

* A safe and highly reliable system should be designed for gas collection.

* Design of biogas burners in large quantity would enhance and encourage the gas utilization all over the world.

* Purification of biogas should be done to enhance other applications of biogas flame such as in welding works and automobiles.

* Development of the process to achieve a high methane percentage in the gas to enable it burn well and also serve as other source of fuel.

* More research should be carried out in the commercialization of the bio-fertilizer, an important residue left after bio-degradation of organic wastes.

* Universal adjuncts such as swine droppings should be added to other organic wastes during anaerobic digestion to increase biogas yields.

\section{REFERENCES}

[1] AOAC (1990). Official Methods of Analysis: Association of Analytical Chemistry. $14^{\text {th }}$ Edition. Washington, U.S.A 22209.

[2] Bell, C., Boulter, S., Dulop, D. and Keiller, P. (1973). In: Methane: Fuel of the Future. Andrew Singer, Cambridge shire, U.K

[3] Bryant, M.P., Barne, J . and Schlegel, H.G. (1976). In : Microbial Energy Conversion. Gottingen,W. Germany, pp. 399 -412.

[4] Bryant, M.P., Wolte, R.S., Wolin, E.A and Wolin, M.J. (1967). “ Journal of Methanobacillus omelianski, A Symbiotic Association of Two Species of Bacteria, 59:20.

[5] Daniels, L., Sparling, R. and Sprott, G.D. (1984). In Biochemical and Biophysiology of Acetogens. Pp. 113 -163.

[6] Dasilva, E.J., Burger, A. and Olembo, R. (1976). Journal of "Health and Wealth from Waste : an Economic Incentive for Developing Countries". $26: 323$. 
[7] Dasilva, E.J., Burger, A. and Olembo, R. (1978). Journal of "Integrated Microbial Technology for Developing Countries. Springboard for Economic progress". 28:159.

[8] Dioha, I.J. Umar, M.K and Okoye, P.A.C. (2003). Studies of the Qualitative and Quantitative Yields of Biogas from Cow Dung and poultry Droppings. A paper for presentative at theNational Solar Energy Forum, NASEF, 2003, at University of Nigeria, Nsukka.

[9] Energy Commission of Nigeria (1998). Rural Renewable Energy Needs and Five Supply Technologies. Pp. 40-42.

[10] ESCAP Document (1975). RAS/74/041/A/01/01, "Biogas Technology and Utilization.” ESCAP, Bank Ok. Pp 17 -33.

[11] Frazier, J.C. and Wolfe, R.S. (1978). Application Environmental Microbiology Medium for the Environment and Isolation of Bacteria from a Organic waste.

[12] Fry, L.G. (1974). Practical Building of Methane Power Plants For Rural Energy Independence. Santa Barabara, California, U.S.A. Pp . 186-208.

[13] George -Okafor, U.O. and Tasie, F.O. (1999). Laboratory Methods in Microbiology. Published by Colours Communications, Enugu, Nigeria.

[14] Fungate, R.E, (1969). Methods in Microbiology.

[15] Imhoff, K. (1938). In: Modern Sewage Disposal. Lancaster press, Lancaster, Penn. Pp. 47-48.

[16] LaRiviere, J.W.M. and Dasiliva, E.J. (1975). In : “ Farming Microbes for Food, Fuel, and Fibre “. UNESCO Courier . pp. 20 -38.

[17] Loll, U. Schiegel, H.G. and Barnea, J,(1976). In : Microbial Conversion. Goffingen, W. Germany, pp. 361-378.

[18] McGarry, M.J. and Stainforth (1978). Compost, Fertilizer and Biogas production in the people's Republic of China, International Development Research Center, Ottawa. Pp. 94-100.

[19] Miles and Misra (1938). Surface Viable Count Method. A Standard Laboratory Technique in Pharmaceutics and Pharmaceutical, Microbiology.

[20] Moigno, A.F. (1882). As Reviewed in Minutes of Proc. In. St. Civil Engineers, XLVIII,350,London

[21] Mynell, P.J. (1982). Methane : planning a Digester. Prism Press, Stable Court, Chatmington, Dovest.

[22] National Academy of Sciences (1977). Methane Generation from Human, Animal and Agricultural Wastes, NAS, Washington D.C. pp.276-289.

[23] Parikh, J. and Parikh (1976). In : Schlegel, H.G and Baranea, J. (Ed.) Microbial Energy Conversion. Gottingen, W. Germany pp.555-591.

[24] Pearson (1996). Chemical Composition and Analysis of Food. In : The Chemical Analysis of Foods. Churchill Livingstone, New York. Pp. 429-431.

[25] Prasad,C.,Prasad,N.and Reddy, A .(1974). Journal of Biogas Plants:Prospects., Problems and Task, Vol.9. 13-47.

[26] Porter, J.R. 91974). Journal of Microbiology and the Disposal of Solid Wastes" Vol. 40. 813-817.

[27] Singh, R.B. (1971). In Biogas plant: Generating Methane from Organic Waste, Gober-Gas Research Station Azitmal, Etawah, India. Pp. 49-58.

[28] Singh, J.B . (1982). Journal of Financing Agriculture, Vol.14, 40-44.

[29] Sowers, K.R. and Ferry, J.G. (1983). In Applied Environmental Microbiology. Pp 684-690.

[30] Torien, D.F. Hattingh, W.H.J., Kotze, J.P., Thiel, P.G., Pretorius, W.A ., Gillie, G.J. and Baillie, R.D. (1970). In : Anacrobic digestion" pp. 384-385.

[31] UNEP (2005). The Future of Bio-Fuel. In : World Energy Concert 47 (5) : 16-19.

[32] Uzodimma, E.O. (2004). Methane production from Cow Dung. Seminar presented at National Center for Energy Research and Development (Unpublished).

[33] Uzodimma, E.O., Ofoefule,A.U. Eze, J.I. and Onwuka, N.D. (2007). Biogas Production from Blends of Agro-industrial Wastes. Trend in Applied Science Research 2 (6): pp. 554 -558.

[34] Walkey Black (1934). A Standard Analytical Laboratory Techniques in theDepartment of soil Science, University of Nigeria, Nsukka.

[35] Young, J.C. and McCarty, P.L (1969). Journal of Microbial Digestion 41(5): 160-173.

[36] Zeikus, J.G. (1977). Chemical and Fuel Production by Anacrobic Bacteria. Ann ,Rev.pp.423-456.

[37] Zeikus, J.G. (1983). Advance e Microbial Physiology.pp.215-24. 